кандидат економічних наук, заступник директора з наукової роботи

Закарпатського регіонального иенттру соціально-економічних $і$ гуманітарних досліджень НАН України

\title{
РОЯЬ ЕТНІЧНОСТІ У ФОРМУВАННІ ЯКОСТІ ЖИТТЯ НАСЕЛЕННЯ
}

Дослідження присвячено теоретичному узагальненню впхиву етнічних характеристик населення на якість його життя. У статті обррунтовано необхідність вивчення якості життя в етнічному вимірі. Наведені наукові результати свідчать про статистично значимий вплив певних світоглядних каналів на якість життя. Дослідження поведінкових каналів, щз формують социіальноеконохічний статус етнічноїгрупи, дають неоднозначнірезультати. Обьрунтовано, що соціально-економічна поведінка окремих етнічних груп обумовлена специбічною комбінацією складових етнічної ідентичності

Ключові слова: добробут, етнос, етнічна ідентичність, меншина, якість життя

The study is devoted to the theoretical generalization of ethnic characteristics of the population influence of on the quality of life. Quality of life is a complex, multidimensional phenomenon that combines objective living conditions with the subjective perception of living standards.

The dynamism and complexity of the "quality of life "phenomenon requires adherence to the principles of multilateralism and taking into account the specificity of the object of study in assessing. Therefore, the article proves the need of researching the quality of life in the ethnic dimension.

The article examines scientific studies that confirms the dependence of quality of life on ethnicity-related characteristics of the population. The phenomenon that regulates the set of characteristics of an ethnos is ethnic identity. Ethnic identity components (behavior, ideal, ethnic self-identification, sense of belonging, pride and affirmation, knowledge of history and traditions, value orientations such as individualism or collectivism, etc.) are considered in the article as possible channels of influence on quality of life.

Thus, the components of ethnic identity can influence both the level of importance of certain spheres of life and the desire to increase that level. At the same time, there is a perception of an ethnic group in another part of society that is often associated with biased attitudes and ethnic stereotypes. They are threatening phenomena and can serve as a basis for justifying discrimination on ethnic (racial, cultural) grounds.

These scientific findings indicate a statistically significant impact of certain vision channels on quality of life. Studies of behavioral channels that shape the socio-eco- 
nomic status of an ethnic group gave mixed results. Accordingly, it is argued that the socio-economic behavior of particular ethnic groups is conditioned by a specific combination of ethnic identity components. This specificity is often associated with ethnic minorities, high levels of isolation of ethnic groups, discrimination (racial, ethnic) and other conditions under which the values of the group can have a significant impact on the life of its members.

Keywords: well-being, ethnicity, ethnic identity, minority, quality of life

"Ethnicity is a highly complex and very much contested concept»[1, c.28]

(Етнічність е вельми складним і надзвичайно спірним поняттям)

В. Бадер

Постановка проблеми. Людиноцентристські погляди у державному управлінні, науці, культурі обумовлюють гостру актуальність дослідження якості життя населення. Результати діагностики якості життя слугують підгрунтям для розробки інструментів забезпечення соціально-економічного розвитку. 3 іншого боку, зміни у суспільстві впливають на метододогії оцінювання якості життя.

Динамічність і складність явища «якості життя» потребуе при його оцінюванні дотримання принципів багатосторонності та врахування специфіки об'єкта дослідження[2]. Тому у разі, коли цілі дослідження пов'язуються з територіями країни, де поряд проживають кілька національностей, необхідне підгрунтя для коректного врахування етнічного фактору при трактуванні результатів.

Аналіз останніх досліджень і публікацій. Західні науковці з 1960-х років почали приділяти увагу різним аспектам якості життя. Залежно від наукового напряму, ці дослідження стосувалися психології (емоційні, когнітивні, ціннісні аспекти); соціології (сприйняття якості життя, задоволеність, щастя, суспільні зв'язки, злочинність), економіки (рівень доходів, доступність продуктів харчування, рівень освіти) тощо. В подальшому синтез різних підходів сформував актуальну на сьогодні об'єктивно-суб'єктивну модель якості життя, що лежить в основі методологій його оцінювання. Крім того, варто звернути увагу, що в західних наукових роботах категорія «якості життя» часто асоціюеться зі станом здоров'я населення. Поряд 3 цим у міжнародних методиках, які характеризують різні об'єктивні та суб'єктивні аспекти якості життя, застосовуються терміни «дюдський розвиток», «добробут», «життєздатність» тощо. В Україні найбільш комплексна робота 3 підготовки методології оцінювання якості життя здійснюеться науковцями Інституту демографії та соціальних досліджень ім. М.В. Птухи.

Впливу етнічності на соціально-економічні процеси приділяли увагу такі українські дослідники: Будкін В., Кравченко Н.В., Пітюлич М.I. Значний доробок в контексті етноекономіки є в авторів з Російської Федерації. Окремі аспекти дослідження впливу етнічності на якість життя широко розкриті вченими з Канади, США, ЄС. Однак контекст їх досліджень ви- 
пливає із наявності у цих країнах депривованих, ізольованих етнічних або расових меншин.

Наразі у західник публікаціях висвітлено результати досліджень, які доводять існування відмінностей між етнічними групами у якості їх життя. Незважаючи на наявний доробок, українські дослідження концентруються на вивченні регіональних диференціацій у якості життя чи окремих іiі компонентів. Водночас етнічний зріз висвітлено лише у невеликій кількості робіт і потребує більш глибокого дослідження та аналізу.

Мета дослідження: теоретичне узагальнення впливу етнічних характеристик населення на якість його життя.

Результати дослідження. Категорія якості життя характеризуе надзвичайно складне явище. Ця складність обумовлена такими обставинами:

- людське життя має багато сфер, якість яких можна оцінювати;

- наявність великої кількості факторів, що динамічно впливають на життя людини або соціальної групи;

- суб'єктивність сприйняття ситуації, у якій знаходиться індивід, якість життя якого оцінюеться.

Всесвітня організація охорони здоров'я визначає якість життя як сприйняття особами своєї життевої позиції в контексті культури та системи цінностей, в якій вони живуть, і стосовно їх цілей, очікувань, стандартів та проблем [3, с.28].

Наразі у світі напрацьовано багато методологічних підходів до оцінювання якості життя у національних масштабах: OECP: BetterLifeIndex, European Quality of Life Surveys (EQLS), Індекс життездатності міст від Тhе Economist Intelligence Unit, Legatum Prosperity Index тощо. Також окремі країни мають власні індекси, що характеризують якість життя у регіональному зрізі. В Україні органами статистики розраховується регіональний індекс людського розвитку. У вказаних методологіях найчастіше виділяються такі сфери якості життя: здоров'я, житлові умови, доходи, громадська активність, суспільне середовище, екологія, безпека, зайнятість, інфраструктура .

Складові, за якими відбувається оцінювання якості життя, тісно між собою взаємопов' язані. Так, фінансовий добробут пов' язаний із типом зайнятості, здоров' ям, освітою. Житлові умови є наслідком добробуту індивіда. Однак значимість складових якості життя у деяких методологіях не вважається однаковою і піддається ваговим коефіцієнтам.

Водночас потрібно мати на увазі, що індивідуальна значимість різних сфер життя обумовлена цінностями конкретної людини. Врахування ціннісних орієнтацій людей присутнє у методологіi OЕСР (Better Life Index) [4], сайт якого дозволяе користувачу визначити вагомість сфер особисто для себе. У результаті результуючі індикатори якості життя аналізованих країн підлаштовуються під окрему особистість і ілюструють «адаптовану» картину.

Саме такий зв' язок лежить в основі обмеження кількості критеріїв для оцінювання якості життя (а отже,і зменшення кількості індикаторів і витрат на здійснення дослідження). 
Роль етнічного чинника уформуванні якості життя стає предметом досліджень у разі проблемності певних етносів і зумовлених нею викликів для соціально-економічних систем.

Прикладами можуть слугувати дослідження ситуації із певними складовими якості життя ромів у ЕС. На початку 2000-х років на рівні міжнародних організацій та утворень організовано дослідження ситуації з ромами. Світовий банк у 2003 році організував конференцію «Роми у Европі, що розширюється: виклики для майбутнього» [5] на якій піднімалися питання цієї національності у Центральному та Східному регіонах Европи шляхом: розширення участі в освіті та праці; підвищення стану здоров' я; покращення умов проживання, зменшення відчуження та дискримінації. У 2004 році Европейською Комісією опубліковано Звіт [6] «Становище ромів у розширеному Європейському Союзі», в якому ситуація з ромами визначається як один із найактуальніших викликів, що стоїть перед Европою.

У 2005 році 12 європейських країн розпочали ініціативу «Десятиліття інтеграції ромів 2005-2015», спрямовану на зменшення нерівності у рівні життя між ромським та іншим населенням, підвищення добробуту, зниження соціального відсудження ромів.

У 2006 році опубліковані результати обстеження під егідою ООН щодо ромів Південно-Східної Европи[7]. А у 2008 році - дослідження ОБСЕ, присвячене міграційним тенденціям серед ромського населення[8]. У 2011 році ПРООН, Світовим банком і СС проведено масштабне опитування домогосподарств ромського населення[9].

Також увага приділяеться етнічній, расовій і мовній складовій у США в контексті порівняння «білого», «чорного» населення, латиноамериканців. У Канаді є розробки в контексті обумовленості стану здоров'я населення його приналежністю до корінного (індіанці).

Відмінні особливості етносів від інших соціальних груп:

1) наявність єдиної мови, спільних рис культури;

2) наявність специфічної самосвідомості, що поділяеться всіма членами етносу, особливих форм солідарності і спільних дій;

3) наявність підвищеної стійкості і адаптивності, що дозволяють довго існувати за історичними мірками;

4) схильність до суттєвих змін у процесі консолідації, асиміляції та етногенезу[10, с.35].

На роль етнічного фактору у соціально-економічних процесах вказували ще А.Сміт., Ф.Діст, М.Вебер, ДЖ. М. Кейнс, И. Шумпетер, В. Зомбарт, Д.Юм. Їх висновки стосувалися макро- (націй) та нанорівня (індивідуального рівня) і передбачали:

- виявлення національних особливостей цілих господарських систем (американців, євреїв, французів, італійців тощо);

- виявлення впливу на економічну поведінку індивіда нераціональних складових, досвіду, стереотипів, культури, традицій, психологічних особливостей тощо.

Ці два підходи не суперечать один одному, а розкривають певний дуалізм етнічної ідентичності. 
«Етнічну ідентифікацію можна визначити як позитивне особисте ставлення та прихильність до групи, з якою індивід вважає, що має спільне походження на основі спільних характеристик та спільного соціокультурного досвіду. Така ідентифікація може відбуватися на різних рівнях, починаючи від осіб до груп та категорій, таких, як етнічність. Так само може бути ідентифікація 3 територією, етнічними інститутами, культурою, історичними символами, ідеологією чи лідерами» [11, с. 150].

Під ідентифікацією Саніна Т. пропонує розгдядати процес,який полягає в усвідомленні індивідом, з одного боку, своєї індивідуальної неповторності, а здругого - своєї схожості із членами групи належності на основі спільних цілей, цінностей та поглядів у рамках внутрішньогрупової та міжгрупової взаємодії [12]. Перелік складових, що формують етнічну ідентичність, охоплюе [13; 14]: поведінку, ідеали; етнічну самоідентифікацію; емоційні складові, такі, як почуття приналежності, гордості та ствердження; когнітивні компоненти, такі, як знання історії та традицій; ціннісні орієнтації, такі, як індивідуалізм чи колективізм; відмінності між компонентами етнічної ідентичності, пов' язані з віком, фенотипом та контекстом.

У контексті сучасних досліджень Кисла Г.О. зазначає, що, «говорячи про роль життєвих цінностей як про фактор інтеграції етносів, ми базуємося на веберівській традиції, у співвідношенні якої життєві цінності служать глибинним регулятором людських дій індивідів і соціальних груп..., забезпечують інтеграцію суспільства, допомагаючи індивідам здійснювати соціально схвальний вибір своєї поведінки в життєво важливих ситуаціях» [15, с.27]. Саме відчуття ідентичності із членами певної етнічної групи є однією з умов побудови соціальної згуртованості етносу.

Згідно з матеріалами соціологічного дослідження «Етнічна самосвідомість особистості», здійсненого Інститутом соціології НАН України, трьома основними етно-ціннісними пріоритетами українського етносу є: мова, почуття до рідної землі і природи, народні звичаї.

Усвідомлення людиною власної належності до певного етносу робить актуальним для неї формування системи етнічних цінностей, яка відповідає потребам, інтересам та нормам етнічної спільноти. Етнічні цінності - це об'єкти, дії, явища, які відображають культуру етносу у духовній та матеріальній формі, створюються та потребуються ним у процесі історичного розвитку [16].

Існування етнічного середовища, з притаманними йому цінностями i поведінковими нормами, формуе підгрунтя для формування унікальних соціальних та економіко-господарських систем. Відповідно до цього виникають нові поняття та наукові напрями: етновалеологія, етноекологія, етноекономіка [10, с.37], етноменеджмент[17], етносоціологія, досліджуються процеси етнічної економіки, етнічного споживання[18].

Отже, з одного боку, етнічні ідентифікація, цінності, норми поведінки, ідеали, уявлення обумовлені більшою мірою внутрішніми характеристиками етносу. 3 іншого - існує сприйняття етнічної групи іншою частиною суспільства, яке часто пов' язують із упередженим ставленням та етнічними стереотипами. 
Етнічний стереотип - це спрощений, схематизований, емоційно забарвлений і надзвичайно стійкий образ етнічної групи, який легко поширюеться на всіх їі представників [19, с. 121].

Блинова О. Е. зазначає, що упереджені уявлення щодо етнічних, суспільних, професійних, соціальних, вікових та інших груп існують у будьякій соціальній спільноті та державі. Особливо яскраве емоційне забарвлення і значну часову стійкість мають етнічні стереотипи. Вони є реальним психологічним феноменом - компонентом установки сприйняття - та відображають культурні відмінності й попередній досвід взаємного спілкування [20, с.72].

Етнічні стереотипи і упередженість е загроздивими феноменами і можуть слугувати основою для виправдання дискримінації за етнічною (расовою, культурною) ознаками. І хоч часи голокосту та апартеїду минули, проте донині упередженість залишається дуже сильною і, що небезпечно, - не явною, прихованою. Наприклад, науковці досліджують явище «демократичного расизму» [21], при якому демократичні принципи (рівність, справедливість тощо) поєднуються з негативно забарвленим ставленням до інших рас: інші раси/меншини не хочуть і не можуть адаптуватися до суспідьства приймаючої країни; не-білі (термін non-whites широко вживається в англомовній літературі) мають менше навичок і мотивації для успіху, культурні проблеми; білі європейські іммігранти також зазнають утисків тощо.

У роботі [22] авторка серед чинників формування ідентичності певного етносу відзначає виняткову важливість типу цієї етнічної групи на певній території (меншина чи більшість), характеру і емоційного забарвлення контактів з членами інших етнічних груп (позитивні чи негативні).

Отже, етнічність впливає на якість життя. Однак постає питання, який характер і вагомість цього впливу. Аналіз існуючих досліджень зв'язку етнічного різноманіття і різних сфер якості життя дозволяе продемонструвати певні тенденції (табл. 1).

Таблицุя 1

Виявдені зв'язки між складовими якості життя та характеристиками, пов'язаними 3 етнічністю

\begin{tabular}{|c|c|c|}
\hline Країна, вибірка & $\begin{array}{c}\text { Складові якості } \\
\text { життя }\end{array}$ & Характеристики зв'язку \\
\hline $\begin{array}{l}\text { Канада (16 ет- } \\
\text { но-культурних } \\
\text { груп)[23] }\end{array}$ & $\begin{array}{l}\text { Щастя, задоволе- } \\
\text { ність життям та за- } \\
\text { доволення загаль- } \\
\text { ною якістю життя }\end{array}$ & $\begin{array}{l}\text { Етнічно/культурні явища пояснюють } 8 \% \text {, } \\
9 \% \text { та } 10 \% \text { варіації балів відповідно за ща- } \\
\text { стя, задоволеність життям та задоволення } \\
\text { із загальною якістю життя }\end{array}$ \\
\hline $\begin{array}{l}\text { Сінгапур (3 ет- } \\
\text { нічні групи)[24] }\end{array}$ & $\begin{array}{l}\text { Фізична активність, } \\
\text { роль фізичних на- } \\
\text { вантажень в обме- } \\
\text { женні життедіяль- } \\
\text { ності, біль, загальний } \\
\text { стан здоров'я, со- } \\
\text { ціальна активність, }\end{array}$ & $\begin{array}{l}\text { Етнічність асоційована з усіма складовими } \\
\text { окрім «загального стану здоров'я», відмін- } \\
\text { ності становили: для китайців (діапазон } \\
\text { значень від 1,4 до 13,1 бала), для малайців } \\
\text { (діапазон 1,9-6,1 бала). } \\
\text { Китайська етнічна належність була пов'я- } \\
\text { зана з більш високими показниками, ніж у }\end{array}$ \\
\hline
\end{tabular}




\begin{tabular}{|c|c|c|}
\hline & $\begin{array}{l}\text { жи т тєздатність, } \\
\text { роль емоційних } \\
\text { проблем в обмежен- } \\
\text { ні життєдіяльності, } \\
\text { психічне здоров'я }\end{array}$ & $\begin{array}{l}\text { індійців: різниці перевищують щонаймен- } \\
\text { ше } 5 \text { балів за } 5 \text { шкалами. Малайці також } \\
\text { показали більші показники порівняно } 3 \\
\text { індійцями } 3 \text { різницею перевищення } 5 \text { ба- } \\
\text { лів за } 1 \text { шкалу (тілесні болі). }\end{array}$ \\
\hline $\begin{array}{l}\text { США (три расо- } \\
\text { ві/етнічні групи: } \\
\text { білі, чорні, лати- } \\
\text { ноамериканці) } \\
\text { [25] }\end{array}$ & $\begin{array}{l}\text { Самооцінка стану } \\
\text { здоров'я, соціаль- } \\
\text { но-економ ічн и й } \\
\text { статус }\end{array}$ & $\begin{array}{l}\text { Виявлено вищий рівень незадоволеності } \\
\text { життям серед меншин (чорні, латиноаме- } \\
\text { риканці) порівняно з білими. Основні пре- } \\
\text { диктори задоволеності життям (безробіт- } \\
\text { тя, інвалідність, самооцінка здоров'я, мар- } \\
\text { кери соціальних відносин) є однаковими } \\
\text { для трьох расових/етнічних груп. Вплив } \\
\text { емоційної підтримки на якість життя мав } \\
\text { расові/етнічні відмінності. }\end{array}$ \\
\hline $\begin{array}{l}\text { Нова Зеландія } \\
(4 \text { етнічні групи) } \\
{[26]}\end{array}$ & $\begin{array}{l}\text { Етнічна ідентич- } \\
\text { ність та особистий } \\
\text { добробут }\end{array}$ & $\begin{array}{l}\text { Національна приналежність і прихильність } \\
\text { мали позитивні зв'язки з особистим добро- } \\
\text { бутом для всіх новозеландців, незалежно } \\
\text { від їх етнічності. Було виявлено відмінно- } \\
\text { сті між відчуттям етнічної приналежності і } \\
\text { особистим добробутом для різних етносів: } \\
\text { для новозеландців європейського похо- } \\
\text { дження і маорі - відсутній суттєвий зв'язок. } \\
\text { Наявний суттєвий статистичний вплив для } \\
\text { тихоокеанських та азіатських народностей. }\end{array}$ \\
\hline $\begin{array}{lr}\text { Північна } & \text { Аме- } \\
\text { рика (метаана- } \\
\text { ліз } 184 & \text { дослі- } \\
\text { джень } & \text { кольо- } \\
\text { рових } & \text { народів } \\
\text { (peopleofcolor)) } \\
{[27]}\end{array}$ & $\begin{array}{l}\text { Сила етнічної іден- } \\
\text { тичності та рівень } \\
\text { особистого добро- } \\
\text { буту }\end{array}$ & $\begin{array}{l}\text { Помірний позитивний зв'язок між двома } \\
\text { конструкціями }(\mathrm{r}=0,17)\end{array}$ \\
\hline
\end{tabular}

*Джерело: укладено автором на основі вказаних джерел

Як видно з даних таблиці, етнічні характеристики та етнічна ідентичність чинить статистично доведений вплив на складові якості життя. Однак на них, зазвичай, припадае лише незначна частка дисперсії аналізованої складової якості життя. Водночас Сміт Т. та Сільва Л. роблять висновок, що етнічна приналежність сприятдиво впливає на добробут саме національних меншин, а не більшості [27]. Також у різних етнічних групах вплив відбувається по- різному.

Дж.Назру стверджує, що зв' язок між етнічною приналежністю і станом здоров' я реалізуеться часто через соціально-економічний статус. Він звертає увагу на результати деяких обстежень, в яких класові ефекти на стан здоров'я подібні для білих та для етнічних меншин [28, с.718]. Відтак автор доходить висновку, що етнічність доцільно розгдядати у двох основних контекстах: у контексті структури, пов'язаної із соціально-економічним статусом членів етносу; у контексті ідентичності і відповідно міжетнічних взаємозв' язків і взаємного сприйняття. Зв' язок між етнічною 
ідентичністю та добробутом був мінімальним у дослідженнях, в яких учасники мали низьку акультурацію до західного суспільства (тобто останніх іммігрантів / біженців) [27]. Щільність етнічної спільноти, контакти між іiі членами, єдність формують додаткові позитивні ефекти як для життя індивіда, так і для соціального капіталу громади.

Синтез вивчених досліджень дозволяє представити загальну модель впливу етнічності на якість життя населення (рис.1).

Отже, соціально-економічні процеси і явища, що формують етнічну ідентичність, є каналами, через які етнос обумовдює якість життя його членів. Цей вплив можливий через два типи каналів. Перший - поведінкові канали, пов'язані з соціально-економічною поведінкою, яка формує певний тип зайнятості, соціальної і просторової мобільності, освітній рівень, ставлення і використання ресурсів. Другий тип каналів - світоглядні, вони обумовлюють сприйняття індивідом свого рівня життя на основі порівнянь із власною або іншою етнічною групою; визначають комфортність перебування у суспільстві на основі соціальної напруженості, відчуття приналежності до групи тощо. Отже,складові етнічної ідентичності можуть впливати як на рівень важливості певних сфер життя,так і на прагнення підвищувати цей рівень.

Статистичний аналіз відображає більш суттєвий вплив складових етнічності на якість життя саме через світоглядні канали. Соціально-економічний статус при цьому впливає на якість життя майже однаково, незалежно від етнічної групи. Однак для окремих етнічних груп усереднений «соціально-економічний» профіль обумовлюеться власне специфічною комбінацією складових етнічної ідентичності.

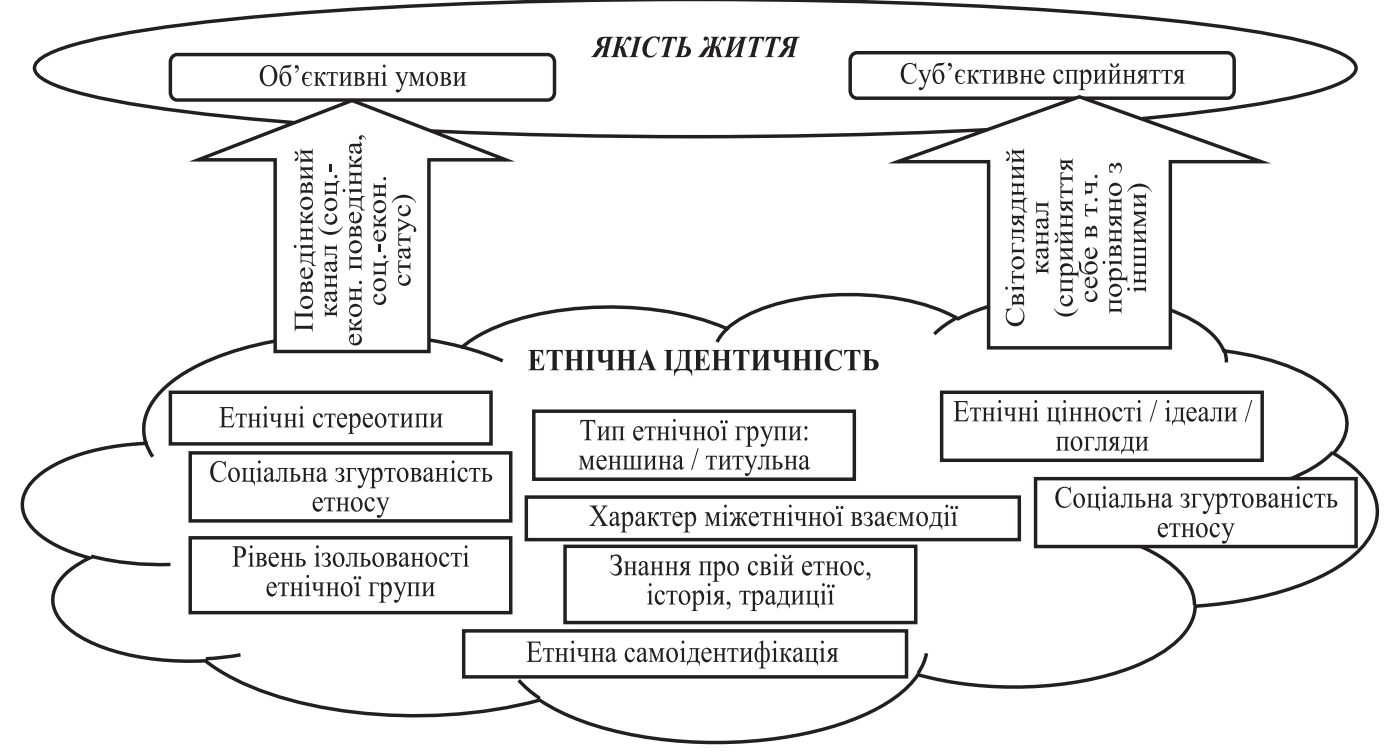

Рис. 1. Модель впливу етнічності на якість життя населення.

*Джерело: розроблено автором 
Висновки і перспективи подальших досліджень. Динамічність і складність явища «якості життя» потребуе при його оцінюванні врахування етнічних характеристик населення на територіях 3 неоднорідним національним складом. Саме складові етнічної ідентичності розглянуто у статті як можливі канади впливу на якість життя. Вони можуть впливати як на рівень важливості певних сфер життя,так і на прагнення підвищувати цей рівень. Водночас існує сприйняття етнічної групи іншою частиною суспільства, яке часто пов'язують із упередженим ставленням та етнічними стереотипами.

Наведені наукові результати свідчать про статистично значимий вплив певних світоглядних каналів на якість життя. Дослідження поведінкових каналів, що формують соціально-економічний статус етнічної групи, дають неоднозначні результати. Відповідно доводиться, що соціально-економічна поведінка окремих етнічних груп обумовлена специфічною комбінацією складових етнічної ідентичності. Ця специфіка часто асоціюється з етнічними меншинами, високим рівнем ізодьованості етнічних груп, дискримінацією (расовою, етнічною) та іншими умовами, за яких цінності групи можуть здійснювати суттєвий вплив на життєдіяльність иї членів.

\section{СПИСОК ВИКОРИСТАНИХ ДЖЕРЕ $Л$}

1. Bader V. Ethnicity and class: a proto-theoretical 'mapping' exercise, in W.W. Isajiw (ed.), Multiculturalism in North America and Europe: Comparative Perspectives on Interethnic Relations and Social Incorporation. - Toronto: Canadian Scholar's Press. 1997. - pp. 103-128.

2. Гаврилова Т.В. Принципы и методы исследования качества жизни населения// Технологии качества жизни. - 2004. - Т. 4, № 2. - С. 1-11.

3. World Health Organization Group. Group development of the World Health Organization WHOQOL-Brief quality of life assessment. Psychological Medicine. - 1998. Vol. 28, pp. 551-558.

4. Organization for Economic Cooperation and Development. OECD Better Life Index. URL: https://www.oecdbetterlifeindex.org/

5. World Bank. Briefing Note. Conference: "Roma in an Expanding Europe: Challenges for the Future." 2003. URL: http://documents.worldbank.org/curated/ en/872391468749375351/Roma-in-an-expanding-Europe- Challenges-for-the-future

6. European Commission Directorate. The situation of Roma in an enlarged European Union. - Luxembourg: Office for official publications of the European Communities, 2004. URL: https://publications.europa.eu/en/publication-detail/-/publication/ b628783f-622a-4e33-9133-141329672d6e

7. United Nations Development Programme. At risk: Roma and the displaced in Southeast Europe. - Bratislava: Regional Bureau for Europe, 2006. URL: https://www.eurasia.undp. org/content/rbec/en/home/library/roma/At-risk-Roma-displaced-Southeast-Europe.html.

8. Cahn C, Guild E. Recent migration of Romain Europe. - Vienna: Organization for Security and Co-operation for Europe, 10 December 2008.URL: http://www.osce.org/ hcnm/78034.

9. Ivanov A., Kling J.. Integrated House hold Surveys among Roma Populations: One Possible Approach to Sampling Usedinthe UNDP-WorldBank-EC Regional Roma 
Survey 2011. - Bratislava: UNDP, 2012.URL: https://www.undp.org/content/dam/ rbec/docs/Roma-household-survey-methodology.pdf

10. Брега Г. Этнические особенности экономического поведения. - Москва: Прометей, 2018. - 186 с.

11. Driedger L. Multi-Ethnic Canada identities and inequalities. - Toronto: Oxford University Press. $-1996 .-352$ p.

12. Саніна Т. О. Дослідження національної та етнічної ідентичності: теоретичний огляд//Наукові записки НаУКМА. Серія Соцііальні науки.- 2005. - Т. 46. -С. 22-26.

13. BernalM. E., KnightG. P., Ocampo K. A., GarzaC. A., CotaM. K. The development of ethnicidentity in Mexican American children//Hispanic Journal of Behavioral Science. -1990.- Vol.12. - pp. 3-24.

14. Phinney J. S. Ethnican dracialidentity: Ethnicidentity//Encyclopedia of psychology. 2000. - Vol. 3. - pp. 254-259.

15. Кисла Г. О. Етносоціальне вимірювання життєвих цінностей особистості// Міжнародний науковий форум: соціологія, психодогія, педагогіка, менеджмент.2010. -Вип. 2. - С. 26-32.

16. Борусевич О.А. Міжпоколінна трансформація етнічних цінностей (на прикладі українського етносу України): автореф. дис. на здобуття наук. ступеня канд. соціол. наук. - Київ, 2000. - 18 с.

17. Павлов К.В. Этноменеджмент и этноэкономика// Економічний вісник Донбасу. - 2016. - № 1(43). - C.131-141.

18. Сюсель Ю.В. Соціальна каузальна атрибуція процесу етнічного споживання// Актуальні проблеми філософї̈ та соціологіï. - 2015. -Вип. 3. - С. 161-165.

19. Євтух В.Б., Трощинський В.П., Галушко К.Ю. Етносоціологія: терміни та поняття: навчальний посібник. - Київ: Фенікс, 2003. - 280 с.

20. Блинова О. Є. Роль етнічних стереотипів у міжкультурному оцінюванні студентської молоді // Проблеми сучасної психологї.- 2014. -Вип. 23. - С. 68-78.

21. Henry R., Tator C., Mattis W., Rees T.TheColour of Democracy: Racism in Canadian Society. - Toronto: Harcourt Brace and Co. Canada.- 1995. - 355 p.

22. Smith E. J. Ethnic identity development: Toward the development of a theory within the context of majority/minority status. Journal of Counseling and Development. - 1991. - Vol.70. - pp.181-188

23. Michalos A. C., ZumboB. D. Ethnicity, modern prejudice and the quality of life. Social Indicators Research. - 2001.- Vol.53(2). - pp. 189-222.

24. Thumboo J., Fong K.-Y., Machin D., Chan S.-P., Soh C.-H., Leong K.-H., Feng P.-H., Thio S., Boey M.L. Quality of life in an urban Asian population: the impact of ethnicity and socio-economic status. Social Science and Medicine. - 2003 . -vol. 56 (8). - pp. 1761-72.

25. Barger S. D., Donoho C. J., Wayment H. A. The relative contributions of race/ethnicity, socioeconomic status, health, and social relationships to life satisfaction in the United States. Quality of Life Research. - 2008. - Vol.18(2). -pp. 179-189.

26. Zdrenka M., Yogeeswaran K., Stronge S., Sibley C. Ethnic and national attachment as predictors of wellbeingamong New Zealand Europeans, Māori, Asians, and Pacific Nations peoples. International Journal of Inter cultural Relations. - 2015. - №. 49. - pp. 114-120.

27. SmithT.B., Silva L. Ethnic Identity and Personal Well-Being of People of Color: A Meta-Analysis. Journal of Counseling Psychology. - 2011. - vol.58. - pp.56-64.

28. Nazroo J. Genetic, cultural or socioeconomic vulnerability? Explaining ethnic inequalities in health//Sociology of Health E Illness. - 1998. - Vol.20 (5). - pp. 710-730. 


\section{REFERENCES}

1. Bader, V. (1997). Ethnicity and class: a proto-theoretical 'mapping' exercise. Multiculturalism in North America and Europe: Comparative Perspectives on Interethnic Relations and Social Incorporation. W.W. Isajiw (Ed.).Toronto: Canadian Scholar's Press[in English].

2. Gavrilova, T. (2004). Princzipy' imetody' issledovani yaka chestva zhizni naseleniya [Principles and methods of researching the quality of life of the population].Tekhnologii kachestva zhizni - Quality of life technology, V. 4, 2, 1-11[in Russian].

3. World Health Organization Group (1998). Group development of the World Health Organization WHOQOL-Brief quality of life assessment. Psychological Medicine, 28, 551-558[in English].

4. Organization for Economic Cooperation and Development. OECD Better Life Index. Retrieved fromhttps://www.oecdbetterlifeindex.org/ [in English].

5. World Bank (2003). Briefing Note. Conference: "Roma in an Expanding Europe: Challenges for the Future." Retrieved from http://documents.worldbank.org/curated/ en/872391468749375351/Roma-in-an-expanding-Europe-Challenges-for-the-future [in English].

6. European Commission Directorate (2004). The situation of Roma in an enlarged European Union. Luxembourg: Office for official publications of the European Communities. Retrieved from https://publications.europa.eu/en/publication-detail/-/publication/b628783f-622a-4e33-9133-141329672d6e [in English].

7. United Nations Development Programme (2006). At risk: Roma and the displaced in Southeast Europe. Bratislava: Regional Bureau for Europe. Retrieved from https:// www.eurasia.undp.org/content/rbec/en/home/library/roma/At-risk-Roma-displaced-Southeast-Europe.html [in English].

8. Cahn, C.,\& Guild, E. (2008). Recent migration of Roma in Europe. Vienna: Organization for Security and Cooperation for Europe. Retrieved from http://www.osce.org/ hcnm/78034 [in English].

9. Ivanov, A.,\&Kling, J. (2012).Integrated House hold Surveysamong Roma Populations: One Possible Approach to Sampling Usedinthe UNDP-WorldBank-EC RegionalRomaSurvey 2011. Bratislava: UNDP. Retrieved from https:/www.undp.org/content/ dam/rbec/docs/Roma-household-survey-methodology.pdf[in English].

10. Brega,G. (2018). E'tnicheskie osobennosti e'konomicheskogo povedeniya. [Ethnic features of economic behavior].Moscow: Prommetey[in Russian].

11. Driedger, L. (1996). Multi-Ethnic Canada Identities and Inequalities. Toronto: Oxford University Press [in English].

12. Sanina, T. (2005). Doslidzhennia natsionalnoi ta etnichnoi identychnosti: teoretychnyi ohliad [Exploring national and ethnic identity: A theoretical overview]. Naukovi zapysky NAuKMA. Ser. Sotsiol. Nauky - NAUKMA Scientific Notes. Series Sociological Sciences, 46,22-26 [in Ukrainian].

13. Bernal, M. E., Knight, G. P., Ocampo, K. A, Garza, C. A., \&Cota, M. K. (1990). The development of ethnicidentity in Mexican American children. Hispanic Journal of Behavioral Science, 2,3-24 [in English].

14. Phinney, J. S. (2000). Ethnic and racial identity: Ethnic identity. Encyclopedia of psychology, Vol. 3, 254-259 [in English].

15. Kysla, H. (2010). Etnosotsialne vymiriuvannia zhyttievykh tsinnostei osobystosti [Ethno-social measurement of the vital values of the individual]. Mizhnarodnyi naukovyi forum: sotsiolohiia, psykholohiia, pedahohika, menedzhment - International scientific forum: sociology, psychology, pedagogy, management, V. 2, 26-32 [in Ukrainian].

16. Borusevych, O. (2000). Mizhpokolinna transformatsiia etnichnykh tsinnostei (na prykladi ukrainskoho etnosu Ukrainy) [Intergenerational Transformation of Ethnic 
Values (on the Example of Ukrainian Ethnicity in Ukraine)]. Extended abstract of candidate's thesis. Kyiv[in Ukrainian].

17. Pavlov, K. (2016). Etnomenedzhment y Etnoekonomyka [Ethnomenagement and Ethnoeconomics]. Ekonomichnyivisnyk Donbasu - Donbass Economic Bulletin, 1(43),131-141 [in Ukrainian].

18. Sussel, Y. (2015). Sotsialna kauzalna atrybutsiia protsesu etnichnoho spozhyvannia [Social causal attribution of the process of ethnic consumption]. Aktualni problemy filosofii ta sotsiolohii - Topical problems of philosophy and sociology, 3,161-165 [in Ukrainian].

19. Ievtukh, V. Troshchynskyi, V.,\&Halushko, K. (2003). Etnosotsiolohiia: terminy ta poniattia [Ethnosociology: Termsand Concepts]. Kyiv: Phoenix [in Ukrainian].

20. Blinova, O. (2014). Rol etnichnykh stereotypiv u mizhkulturnomu otsiniuvanni studentskoi molodi [The role of ethnics tereotypes in intercultural assessment of student youth]. Problemy suchasnoi psykholohii - Problems of modern psychology, 23, 68-78 [in Ukrainian].

21. Henry, R., Tator, C., Mattis, W., \&Rees, T. (1995). The Colour of Democracy: Racism in Canadian Society. Toronto: Harcourt Brace and Co. Canada. [in English].

22. Smith, E. J. (1991). Ethnic identity development: Toward the development of a theory within the context of majority/minority status. Journal of Counseling and Development, 70, 181-188 [in English].

23. Michalos, A. C. ,Zumbo,B. D. (2001). Ethnicity, modern prejudice and the quality of life. Social Indicators Research., №53(2), pp. 189-222. [in English].

24. Thumboo, J., Fong, K.-Y., Machin, D., Chan, S.-P., Soh, C.-H., Leong, K.-H. ... Boey, M.L.(2003). Quality of life in an urban Asian population: the impact of ethnicity and socio-economic status. Social Scienceand Medicine,56 (8), 1761-72 [in English].

25. Barger, S. D., Donoho, C. J., \&Wayment, H. A. (2008). The relative contributions of race/ethnicity, socioeconomic status, health, and social relationships to life satisfaction in the United States. Quality of Life Research, 18(2), pp. 179-189 [in English].

26. Zdrenka, M., Yogeeswaran, K., Stronge, S.,\&Sibley, C. (2015). Ethnic and national attachment as predictors of wellbeingamong New Zealand Europeans, Māori, Asians, and Pacific Nationspeoples. International Journal of Intercultural Relations, 49, 114-120 [in English].

27. Smith,T.B., Silva, L. (2011). Ethnic Identity and Personal Well-Being of People of Color: A Meta-Analysis. Journal of Counseling Psychology, 58, 56-64 [in English].

28. Nazroo, J. (1998). Genetic, cultural or socioeconomic vulnerability? Explaining ethnic inequalities in health. Sociology of Health $\mathcal{E}$ Illness, 20(5), 710-730 [in English]. 